\title{
INVESTIGATION OF MYCOPLASMA SYNOVIAE SEROPREVALENCE IN BROILER BREEDER FARMS IN SOUTH BAČKA REGION
}

Milena Samojlovićc ${ }^{\star}$, Marko Pajić1 , Biljana Božić1 ${ }^{1}$, Slobodan Knežević ${ }^{1}$, Miloš Pelić ${ }^{1}$, Dalibor Todorović ${ }^{1}$, Sava Lazić ${ }^{1}$

${ }^{1}$ Scientific Veterinary Institute "Novi Sad", Rumenački put 20, Novi Sad, Serbia

\section{Abstract}

Mycoplasma synoviae is known to cause respiratory disorders, synovitis, subclinical infections, air sacculitis and eggshell apex abnormalities in domestic poultry worldwide. The aim of this study was to determine $M$. synoviae seroprevalence in 5 different broiler breeder farms in South Bačka from 2014 to 2017. A total of 1511 samples were tested using commercial indirect enzyme linked immunosorbent assay (ELISA) for detection of antibodies in the blood sera. In this study, the seroprevalence of $25.21 \%$ was found and 47 (40.87\%) flocks out of 115 tested were positive to M.synoviae. Seroprevalence varied between $31.02 \%$ in 2015 and $16.78 \%$ in 2016. Flock prevalence ranged from $31.03 \%$ in 2014 to $55.88 \%$ in 2015 . These results suggest that $M$. synoviae infection is present in broiler breeder farms in South Bačka, and that is necessary to conduct further research, systematic monitoring and to improve biosecurity measures on broiler breeder farms.

Key words: Mycoplasma synoviae, seroprevalence, broiler breeder

\footnotetext{
${ }^{1 *}$ Corresponding author: milena.s@niv.ns.ac.rs
} 


\title{
SEROPREVALENCA MYCOPLASMA SYNOVIE NA FARMAMA RODITELJSKIH JATA TEŠKIH LINIJA U JUŽNOBAČKOM OKRUGU
}

\author{
Milena Samojlovićc ${ }^{*}$, Marko Pajić1 , Biljana Božić ${ }^{1}$, Slobodan \\ Knežević1, Miloš Pelić ${ }^{1}$, Dalibor Todorović ${ }^{1}$, Sava Lazić ${ }^{1}$ \\ ${ }^{1}$ Naučni institut za veterinarstvo "Novi Sad”, Rumenački put 20, Novi Sad, Srbija
}

\section{Kratak sadržaj}

Poznato je da Mycoplasma synoviae uzrokuje respiratorna oboljenja, sinovitis, subkliničke infekcije, zapaljenje vazdušnih vreća i deformitete ljuske jaja kod domaće živine širom sveta. Cilj ovog istraživanja bio je da se utvrdi seroprevalenca $M$. synoviae na 5 različitih farmi roditeljskih jata teških linija od 2014. do 2017. godine. Indirektnom ELISA tehnikom ukupno je testirano 1511 krvnih seruma. Utvrđena je seroprevalenca od 25.21\%, a od 115 testiranih jata $47(40.87 \%)$ je bilo pozitivno na antitela protiv $M$. synoviae. Seroprevalenca se kretala od $16.78 \%$ u 2016. godini do $31.02 \%$ u 2015. godini. Prevalenca jata je iznosila od 31.03\% u 2014. godini do $55.88 \%$ u 2015. godini. Rezultati dobijeni u ovom istraživanju ukazuju da je infekcija $M$. synoviae prisutna na farmama roditeljskih jata teških linija u Južnobačkom okrugu i da je neophodno sprovesti dalja istraživanja, sistemski monitoring i poboljšati mere biosigurnosti na farmama.

Ključne reči: Mycoplasma synoviae, seroprevalenca, roditeljska jata teških linija

\section{INTRODUCTION}

Mycoplasma synoviae (Ms) is one of the most important pathogens in domestic poultry worldwide, including breeders, broilers and layers (Vardaman et al., 1973; Kleven and Ferguson - Noeln, 2008). Ms infections in poultry have always been regarded as less important than infections with Mycoplasma gallisepticum, but during the last decade, the importance of infections with Ms have been highlighted in several researches and there is an increased consciousness to produce Ms free poultry (Feberwee et al., 2008; Landman, 2014). In chickens, Ms infections have been associated with the respiratory disorders, synovitis, subclinical infections, air sacculitis (Vardaman et al., 1973; Macowan 
et al., 1984), as well as eggshell apex abnormalities and egg production losses (Landman and Feberwee, 2001; Van Beek et al., 2002; Landman and Feberwee, 2004; Feberwee et al., 2007).

Mycoplasma synoviae can cause significant economic losses due to decrease of egg production rate, growth and hatchability rates, poor eggshell quality, and condemnation of carcasses at slaughter because of air sacculitis and arthritis (Fiorentin et al., 2003; Kleven 2003a; Peebles et al., 2011). An additional contribution to the importance of Ms infection in domestic poultry is brought by the high seroprevalence of Ms in countries with developed poultry industry (Feberwee et al., 2008; Feberwee and Landman, 2012) and its ability to interact with other pathogens such as Newcastle disease virus and infectious bronchitis virus (Kleven et al., 1972; Hopkins and Yoder, 1982; Feberwee et al., 2009). Reduction in egg production of 5 to $10 \%$, a reduction in hatchability of 5 to $7 \%$ and more than $5 \%$ increased mortality in the young chickens were reported in infected breeder flocks (Stipkovits and Kempf, 1996). Broiler flocks from the seropositive broiler breeders showed higher rate of mortality from air sacculitis (King et al., 1973; Macowan et al., 1984). The economic impact of Ms infection is mainly focused on increased condemnation of carcasses due to air sacculitis (Sentíes-Cué et al., 2005). Reduced weight gain and poorer feed conversion are also the result of Ms infection in broilers (King et al., 1973). Mycoplasma synoviae can be transmitted horizontally and vertically (Jordan, 1975). Vertical transmission is considered to be a major way of spreading of Ms in domestic chickens, therefore the most efficient method of control would be regular monitoring and elimination of positive breeder flocks (Kleven and Ferguson-Noeln, 2008; Lockaby et al., 1998). Although various live and attenuated Ms vaccines have been developed and used worldwide (Morrow et al., 1998), the Ms vaccine is not yet available in Serbia.

In Serbia, serological monitoring of Ms is still on voluntary basis and data about seroprevalence of Ms in poultry farms are lacking. It is necessary to identify Ms seropositive farms, to assess the epidemiological risks in different poultry categories and to improve biosecurity measures on farms. The aim of this study was to investigate Ms seroprevalence on different broiler breeder farms and to perceive the epidemiological situation of Ms infection in South Bačka Region.

\section{MATERIAL AND METHODS}

A total of 1511 blood samples were taken from 115 broiler breeder flocks from 5 different farms in South Bačka region. The samples were taken from 
2014 to 2017, following the voluntary M. synoviae control program established by Scientific Veterinary Institute "Novi Sad". Blood samples were aseptically taken from non-vaccinated broiler breeders that had no clinical symptoms.

Sera were tested for the presence of antibodies to M. synoviae by a commercial ELISA test kit (IDEXX 99-06728, IDEXX Laboratories, Westbrook, $\mathrm{ME}$ ) according to manufacturer's instructions. Briefly, $100 \mu \mathrm{l}$ of each diluted serum sample (1:500) were added to the wells previously coated with Ms antigen. Undiluted positive and negative controls were tested in duplicate wells. Samples were incubated at $18-26^{\circ} \mathrm{C}$ for 30 minutes. After washing the plates with distilled water 3 to 5 times, $100 \mu \mathrm{l}$ of conjugate (Goat antichicken antibodies: Horseradish peroxidase conjugate) were added to each well and incubated at $18-26^{\circ} \mathrm{C}$ for 30 minutes. Plates were washed again 3 to 5 times with distilled water and $100 \mu \mathrm{l}$ of TMB (tetramethyl benzidine) substrate were dispensed into each well of the plate. The substrate solution was incubated at $18-26^{\circ} \mathrm{C}$ for 15 minutes. The reaction was quenched with $100 \mu \mathrm{l}$ of stopping solution. The absorbance was measured at $650 \mathrm{~nm}$. Serum samples with $\mathrm{S} / \mathrm{P}$ values greater than 0.5 (titer greater than 1076) were considered positive.

\section{RESULTS}

The obtained results are presented in Table 1 and Table 2. In general, 381 samples were found positive for the presence of anti-Ms antibodies, with the overall prevalence of $25.21 \%$. The highest $-31.02 \%$ and the lowest $-16.78 \%$ seroprevalence was found in 2015 and 2016, respectively (Table 1). It was found that $47(40.87 \%)$ out of the 115 tested flocks were positive. Positive flock rates in different years ranged between $31.03 \%$ and $55.88 \%$ (Table 2).

Table 1. Seroprevalence of Ms from 2014 to 2017

\begin{tabular}{|c|c|c|c|}
\hline Year & $\begin{array}{c}\text { Number of } \\
\text { tested samples }\end{array}$ & $\begin{array}{c}\text { Number of posi- } \\
\text { tive samples }\end{array}$ & $\begin{array}{c}\text { Prevalence } \\
(\%)\end{array}$ \\
\hline 2014 & 361 & 100 & 27.70 \\
\hline 2015 & 432 & 134 & 31.02 \\
\hline 2016 & 453 & 76 & 16.78 \\
\hline 2017 & 265 & 71 & 26.79 \\
\hline Total: & $\mathbf{1 5 1 1}$ & $\mathbf{3 8 1}$ & $\mathbf{2 5 . 2 1}$ \\
\hline
\end{tabular}


Table 2. Results of the presence of Ms in poultry flocks from 2014 to 2017

\begin{tabular}{|c|c|c|c|}
\hline Year & $\begin{array}{c}\text { Number of tested } \\
\text { flocks }\end{array}$ & $\begin{array}{c}\text { Number of positive } \\
\text { flocks }\end{array}$ & $\begin{array}{c}\text { Positive rates } \\
(\%)\end{array}$ \\
\hline 2014 & 29 & 9 & 31.03 \\
\hline 2015 & 34 & 19 & 55.88 \\
\hline 2016 & 33 & 12 & 36.36 \\
\hline 2017 & 19 & 7 & 36.84 \\
\hline Total & $\mathbf{1 1 5}$ & $\mathbf{4 7}$ & $\mathbf{4 0 . 8 7}$ \\
\hline
\end{tabular}

\section{DISCUSSION}

Mycoplasma synoviae is one of the most important mycoplasma species that affect domestic poultry during laying period. Our results revealed Ms infection seroprevalence of $25.21 \%$ in broiler breeders. Another study conducted in Serbia showed seroprevalence of $36.66 \%$ in 2000 and $22.60 \%$ in 2009 . The decrease in seropositivity in 2009 compared to 2000 was due to specific measures that were applied in layer and broiler breeder flocks (Kapetanov et al., 2010). Similar serological survey in China demonstrated an overall seroprevalence of $41.19 \%$, which is twice as high in comparison to our results. Seroprevalence in China varied in different provinces from $5.10 \%$ to $100 \%$. Commercial vaccine is not yet available in China, so the authors concluded that detected antibodies originated from the natural infection (Xue et al., 2017). In Serbia, the situation in view of the availability of vaccine against $\mathrm{Ms}$ is the same as the one in China, so our results indicated seroconversion following natural infection as well. A study in Portugal revealed Ms seroprevalence of 40.3\% (Moreira et al., 2015), which is similar to the one found in China.

Survey in Portuguese broiler breeder flocks revealed high prevalence of Ms infection, with 483 positive samples and $24(66.7 \%)$ positive flocks out of 36 tested (Moreira et al., 2015). In the Netherlands, flock prevalence was $35 \%$ (Feberwee et al., 2008), in South America 15\% (Buim et al., 2009) and in Middle East $27 \%$ (Amer et al., 2012). In our study, flock prevalence was $41 \%$, which is lower in comparison to those from Portuguese flocks, and higher in comparison to other above-mentioned results. These results suggest worldwide distribution of Ms infection in breeder flocks. Another study addressing the Ms flock prevalence was carried out in Serbia by Kapetanov et al. (2010), and the authors reported flock prevalence of 40.48 in 2000 and 20.74\% in 2009. Flock prevalence in our study varied from $31.03 \%$ in 2014 to $55.88 \%$ in 2015 . It can 
be concluded that Ms flock prevalence is different from year to year, because the occurrence of infection is influenced by numerous factors.

Since Ms can be transmitted vertically and horizontally (Stipkovits and Kempf, 1996), it can cause infection in broilers with increased mortality, feed conversion and condemnation. (Xue et al., 2017; Moreira et al., 2015). Feberwee et al. (2008) reported lower seroprevalence in meat rearing breeder stock (6\%) than in meat-type grandparents stock $(10 \%)$, due to reduced risk of vertical transmission by elimination of Ms-positive flocks. Authors also found higher seroprevalence in meat production breeder stock (35\%) than in meat rearing breeder stock. The accuracy of the estimated seroprevalence could have been influenced by frequency and number of birds sampled per flock, which was different for different poultry categories (Feberwee et al., 2008). In order to establish reliable Ms control and prevention program sampling methods, sample size and poultry categories must be determined in advance. High prevalence of Ms infection was found in Portuguese breeder farms, so the authors suggested that culling Ms-positive flocks with such a high prevalence is not an option (Moreira et al., 2015). On the other hand, elimination of positive breeder flocks is recommended, if possible, as one of the best solutions when there is a low Ms prevalence (Buim et al., 2009; Feberwee et al., 2008). The elimination of positive flocks is not carried out in Serbia, but infected flocks are treated with appropriate medications. The use of medications to treat Ms infection increases the production costs. Although vaccines and medication can reduce clinical signs and economic impact of Ms infection, medication cannot completely eliminate mycoplasma infections (Whithear, 1996; Kleven 2003a) and vaccines are not yet available in all countries, such as China and Portugal (Moreira et al., 2015; Xue et al., 2017) as well as Serbia. Ms are capable of establishing lifelong infections in poultry, and that can be one of the reasons for inability to eradicate Ms in commercial poultry flocks, especially in breeders that stay a long period in rearing and production sites.

\section{CONCLUSION}

It is evident that Ms is present on broiler breeder farms in South Bačka. In the absence of systematic monitoring of Ms infection in Serbia, further studies need to be done to obtain an overall picture of Ms prevalence in our country. Serological monitoring of Ms infection plays an important role in the prevention and control of this infection in poultry. Besides, it is also important to improve biosecurity measures on farms and to import broiler breeder chickens only from the farms that conduct vaccination against Ms. It is recommendable 
to introduce vaccination against Ms in all broiler breeder farms in Serbia, as one of the most significant prevention measures.

\section{ACKNOWLEDGEMENTS}

This investigation was supported by grants from the Ministry of Education, Science and Technological Development of the Republic of Serbia, Project No. 31071 and Project No. 31084.

\section{REFERENCES}

1. Amer M.M. Zohair G.A. El-Bayomi K.M. Amin Girh Z.M.S., Amer M.: Effect of Tilmicosin in Control of Mycoplasmosis in Broiler Chickens from Infected Breeders Using Elisa Test for Evaluation. Journal of American Science, 8, 83, 696-700, 2012.

2. Van Beek P., Feberwee A., Fabri T.H.F., Heijmans M.: Longitudinal field study on the presence of Mycoplasma synoviae in meat-turkey flocks with arthritis. Proceedings of the 4th International Symposlum on Turkey Diseases, 177-178, 2002.

3. Buim M.R., Mettifogo E., Timenetsky J., Kleven S., Ferreira A.J.P.: Epidemiological survey on Mycoplasma gallisepticum and M. synoviae by multiplex PCR in commercial poultry. Pesquisa Veterinária Brasileira, Colégio Brasileiro de Patologia Animal, 29, 7, 552-556, 2009.

4. Feberwee A., Landman W.J.M.: The successful implementation of Mycoplasma gallisepticum monitoring and control programmes in Dutch commercial poultry: a declining seroincidence during an eleven year period. Proceedings of 19th Congress of the International Organization for Mycoplasmology, Toulouse, France, 153, 2012.

5. Feberwee A., De Vries T.S., Landman W.J.M.: Seroprevalence of Mycoplasma synoviae in Dutch commercial poultry farms. Avian Pathology, 37, 6, 629-633, 2008.

6. Feberwee A., de Wit J.J., Landman W.J.M.: Mycoplasma synoviae associated eggshell apex abnormalities. The 15th Congress \& Exhibition of the World Veterinary Poultry Association, 10-15, 2007.

7. Feberwee A., De Wit J.J., Landman W.J.M.: Induction of eggshell apex abnormalities by Mycoplasma synoviae: Field and experimental studies. Avian Pathology, 38, 1, 77-85, 2009.

8. Fiorentin L., Soncini R.A., Da Costa J.L.A., Mores M.A.Z., Trevisol I.M., Toda M., Vieira, N.D.: Apparent eradication of Mycoplasma synoviae in 
broiler breeders subjected to intensive antibiotic treatment directed to control Escherichia coli. Avian Pathology, 32, 2, 213-216, 2003.

9. Hopkins S.R., Yoder Jr., H.W.: Influence of infectious bronchitis strains and vaccines on the incidence of Mycoplasma synoviae airsacculitis. Avian Diseases, 26, 4, 741-752, 1982.

10. Jordan F.T.W.: Avian mycoplasma and pathogenicity - a review. Avian Pathology, 4, 3, 165-174, 1975.

11. Kapetanov M., D. Orlić D. Potonjak M. Velhner I., Stojanov D. Milanov D.S.: Mycoplasma in poultry flocks in the year 2009 compared to the year 2000 and significance of the control measures. Lucrari Stiintifice Medicina Veterinara, 1, 249-253, 2010.

12. King D.D., Kleven S.H., Wenger D.M., Anderson, D.P.: Field Studies with Mycoplasma synoviae. Avian Diseases, 17, 4, 722-726, 1973.

13. Kleven S.H., King D.D., Anderson D.P.: Airsacculitis in broilers from Mycoplasma synoviae: effect on air-sac lesions of vaccinating with infectious bronchitis and Newcastle virus. Avian Diseases, 16, 4, 915-924, 1972.

14. Kleven S.H.: Mycoplasma synoviae infection. In: Diseases of Poultry, 11th Ed., Iowa press, Iowa, 756-766, $2003 \mathrm{a}$.

15. Kleven S. H., Ferguson-Noeln N.: Mycoplasma synoviae infection. In: Diseases of Poultry, 12 e.d. Blackwell Publishing, Iowa State University Press, USA, Ames: Iowa, 845-856, 2003 b.

16. Kleven S.H., Ferguson-Noeln N.: Mycoplasma synoviae infection. In: Diseases of Poultry, 12.ed. Blackwell Publishing, Iowa State University Press, USA, Ames: Iowa, 845-56, 2008.

17. Landman W.J.M.: Is Mycoplasma synoviae outrunning Mycoplasma gallisepticum? A viewpoint from the Netherlands. Avian Pathology, 43, 1, 2-8, 2014.

18. Landman W.J.M., Feberwee A.: Field studies on the association between amyloid arthropathy and Mycoplasma synoviae infection, and experimental reproduction of the condition in brown layers. Avian Pathology, 30, 6, 629-639, 2001.

19. Landman W.J.M., Feberwee, A.: Aerosol-induced Mycoplasma synoviae arthritis: The synergistic effect of infectious bronchitis virus infection. Avian Pathology, 33, 6, 591-598, 2004.

20. Lockaby S.B., Hoerr F.J., Lauerman L.H., Kleven, S.H.: Pathogenicity of Mycoplasma synoviae in broiler chickens. Veterinary Pathology, 35, 3, 178-190, 1998.

21. Macowan K.J., Atkinson M.J., Bell M.A., Brand T.F., Randall C.J.: Egg transmission of a respiratory isolate of mycoplasma synoviae and infection of the chicken embryo. Avian Pathology, 13, 1, 51-58, 1984. 
22. Moreira F.A., Cardoso L., Coelho A.C.: Epidemiological survey on Mycoplasma synoviae infection en Portuguese broiler breeder flocks. Veterinaria Italiana, 51, 2, 93-98, 2015.

23. Morrow C.J., Markham J.F., Whithear K.G.: Production of temperaturesensitive clones of Mycoplasma synoviae for evaluation as live vaccines. Avian Diseases, 42, 667-670, 1998.

24. Peebles E.D., Park S.W., Branton S.L., Gerard P.D., Womack S.K.: Dietary poultry fat, phytase, and 25-hydroxycholecalciferol influence the digestive and reproductive organ characteristics of commercial layers inoculated before or at the onset of lay with F-strain Mycoplasma gallisepticum. Poultry Science, 90, 4, 797-803, 2011.

25. Sentíes-Cué G., Shivaprasad H.L., Chin R.P.: Systemic Mycoplasma synoviae infection in broiler chickens. Avian Pathology, 34, 2, 137-142, 2005.

26. Stipkovits L., Kempf I.: Mycoplasmoses in poultry. Revue Scientifique et Technique (International Office of Epizootics), 15, 4, 1495-1525, 1996.

27. Vardaman T.H., Reece F.N., Deaton J.W.: Effect of Mycoplasma synoviae on broiler performance. Poultry Science, 52, 5, 1909-1912, 1973.

28. Whithear K.G.: Control of avian mycoplasmoses by vaccination. Revue Scientifique et Technique (International Office of Epizootics), 15, 4, 15271553, 1996.

29. Xue J., Xu M.Y., Ma Z.J., Zhao J., Jin N., Zhang G.Z.: Serological investigation of Mycoplasma synoviae infection in China from 2010 to 2015. Poultry Science, 96, 9, 3109-3112, 2017.

Primljeno: 11.11.2017.

Odobreno: 26.12.2017. 